\title{
PATRONES DE REASENTAMIENTO: UNA APROXIMACIÓN DIGITAL CUANTITATIVA Y EXPLORATORIA DE LOS EXILIADOS REPUBLICANOS DE PRIMERA GENERACIÓN QUE REGRESARON A ESPAÑA (1939-2010)
}

\section{Resettlement patterns: a quantitative and exploratory digital approximation of first-generation Republican exiles who returned to Spain (1939-2010).}

\author{
Mauricio Escobar Deras \\ Universidad de Granada, Instituto de Migraciones \\ mauiricio.descobar@gmail.com \\ Orcid: 1-7899-0196
}

\section{Cómo citar este artículo/Citation:}

Mauricio Escolar Deras, "Patrones de reasentamiento: una aproximación digital cuantitativa y exploratoria de los exiliados republicanos de primera generación que regresaron a España (1939-2010)", Hispania Nova, 1 Extraordinario (2021): 152 a 168.

DOI: https://doi.org/10.20318/hn.2021.6182
Copyright: (C) HISPANIA NOVA es una revista debidamente registrada, con ISSN 1138-7319 y Depósito Legal M 9472-1998. Los textos publicados están -si no se indica lo contrario- bajo una licencia Reconocimiento-Sin obras derivadas 3.0 España de Creative Commons. Puede copiarlos, distribuirlos y comunicarlos públicamente siempre que cite su autor y la revista y la institución que los publica y no haga con ellos obras derivadas. La licencia completa se puede consultar en: http://creativecommons.org/licenses/by-nd/3.0/es/deed.es

\begin{abstract}
Resumen: Esta investigación explora los datos cuantificables de ciento cincuenta y ocho exiliados republicanos de primera generación, según el año de repatriación a España (de 1939 a 2010), y sus opciones de reasentamiento una vez en el país. Los datos obtenidos provienen de la fusión de dos bases de datos, creadas ad hoc, que se consultaron para ver si estos exiliados regresaron a su lugar de nacimiento, después de su período de exilio, o si eligieron una ciudad diferente para reincorporarse a la sociedad española. Las diferencias de género se examinan moderadamente para explorar las diferencias entre las mujeres que optaban por regresar a sus ciudades nativas y los hombres que optaban por lugares diferentes debido a fuerzas externas. Llegamos a una serie de conclusiones que se
\end{abstract}

pueden aplicar al fenómeno del retorno en general, correlacionándose el fuerte vínculo entre el tiempo pasado en el exilio y la probabilidad, o falta de ella, de regresar a la ciudad de origen. De este modo, nos ayuda a discernir la adaptación, o no, a la sociedad española.

Palabras clave: Retorno, repatriación, exilio republicano, humanidades digitales, mujeres. 


\begin{abstract}
This research explores the quantifiable data of 158 first-generation Republican exiles based on the year of repatriation to Spain (from 1939 to 2010), and their resettlement choices once in the country. The data was obtained from the merging of two ad hoc databases, queried to see if the individuals returned to their birthplace after their exile period or if they chose a larger or smaller city to re-incorporate into Spanish society. Gender differences are moderately examined to explore variances between women favoring their birth cities and men's movement away from their hometowns due to external forces. We reached a series of conclusions that can be tentatively applied to the greater return experience and correlated a strong link between time spent in exile and the likelihood, or lack thereof, of returning to the city of origin. In so doing, helping to discern the adaption back into Spanish society.
\end{abstract}

Keywords: Return, Repatriation, Republican Exile, Digital Humanities, women.

\title{
INTRODUCTION
}

The Spanish Civil War (1936-1939) displaced half a million people, most of them into France. The majority repatriated back to Spain within a year and half of the end of the conflict. However, for the over one hundred thousand people that remained outside of Spain, the average period of exile would last 25 years (Soo 2014, 40-44). This group, as well as other peninsula-born individuals who emigrated after the civil war, became the first generation of Spanish exiles. A first-generation individual is a refugee of the Spanish Civil War who was directly affected by either the bellicose period, or its aftermath, and later lived in exile ${ }^{1}$. The total number of first-generation refugees that remained in exile or that repatriated back to Spain is unknown (Ortuño Martínez 2015, 127). This is partly due to emphasis on the bellicose period of the war and the subsequent human condition and plight of the exiles. The repatriation aspect (temporary or permanent; immediate or otherwise, which herein will be referred to as the return, if self-motivated), has been largely overlooked, and until recently, only

\footnotetext{
${ }^{1}$ First-generation also includes individuals born in Spain after the civil war and who were forced to emigrate because of it. Their displacement from Spain would need to have been a direct result of the civil war itself. For example, V. C. Farga was born in 1943 in Barcelona, but due to his family's physical and political hardship, his parents emigrated to Mexico in 1950. He returned to Barcelona 59 years later in 2009 at the age of 66. See 'Encuesta del exiliado Retornado' Published September 28, 2018, https://docs.google.com/forms/d/1xnmC8WqMlq4fv38FYjp_asWE_16IYovnY0m1oMjIavE/edit.
} 
sporadically noted. Focus was given to notable individuals like Salvador Dali, who returned to Spain in 1948, intellectuals like Rafael Alberti (returned in 1977), or Civil War political figures such as "La Pasionaria” Dolores Ibárruri (returned in 1977). This oversight in the academic field began changing in the late 1990s when Alicia Alted Vigil and Josefina Bustillo, in their respective works, shifted the exile focus to that of the return of exiles (Alted Vigil 1999; Bustillo Cuestas 1999). As well as the testimony of Adolfo Sánchez Vázquez, a first-generation refugee in Mexico who concluded that the exile period never ended, including for the individuals who returned to Spain (Sánchez Vásquez, 1997, 27-38). Their repatriations became a new focus for researchers like Carmen González Martínez (2003) who analysed the lives of exiled children and their mixed reception and adaptation back into their families and Spanish society in general. Later, Pozo-Gutierrez Alicia and Scott Soo (2010) categorized the various refugee and migrant returns to Spain after Francisco Franco's first "pardon". More recently, Abdón Mateos López (2015) focused on prominent exiled socialist and their repatriations back to Spain following their political pursuits after the death of Franco in 1975. Likewise, Rosy Rickett (2015) and Lidia Bocanegra Barbecho (2015) each have scholarly works that look into the return experiences of former exiles, and how these affect the collective historical memory. Further still, the interest in the Civil War and Exile has extended to online networks and collectively come under the umbrella of digital humanities ${ }^{2}$. However, the Return phenomenon once more has not had a central focus.

Although the study of the return has gained the attention of researchers, there is still a dearth of scholarship that examines it at the macro-level and over the eight decades that followed the Civil War. This paper aims to aggregate, quantify and begin a general exploratory dialogue about the return experience by specifically focusing on where individuals resettled once they returned to Spain and their reasoning for doing so. We will also identify general trends from the datasets that can then be tentatively extended to the return phenomenon as a whole. It will not directly address the

\footnotetext{
${ }^{2}$ See Centro Documental de la Memoria Histórica (CDMH), accessed April 20, 2021, http://www.culturaydeporte.gob.es/cultura/areas/archivos/mc/archivos/cdmh/portada.html. See also Proyecto Historia y Memoria (HISMEDI), accessed April 20, 2021, https:/humanidadesdigitales.uc3m.es/s/hismedi-g/page/inicio
} 
assimilation experience back into Spanish society but it will however speculate on the social-political conditions surrounding the various return groupings.

\section{METHODOLOGY}

Two distinct databases on returnees were combined into one online database that included the date and city of birth, year of return and the city of residency or death for each individual. The sources of the two databases are the Returnee Data Literary Studies (RD-LS), and the Returnee Data in Social Networks (RD-SN), which both are part of the E-xiliad@s project $^{3}$ repository of exiled Republican individuals (Bocanegra Barbecho 2021). The first databases is composed of data from 200 exiles (all generations), who were repatriated, or returned of their own accord to Spain, and who are identified in various literary mediums - including books, newspapers and academic journals - by various researchers who investigate Spanish diaspora. Included in the database are five individuals that were originally found in the general Exiliad@s open access database (Bocanegra Barbecho 2014, 60-63). At the time of writing, the RD-SN database is composed of 57 exiles that returned to Spain and whose information was filled out and submitted by relatives or friends of the returnee via an online questionnaire. Its intended focus was to identify unknown returnees and ascertain the ease or difficulty of readapting to Spanish society.

Combining both databases, we identified 233 first-generation individuals who returned to Spain. Of these, 26 individuals $(11.1 \%)$ were known to have returnedhowever their exact year of return could not be identified. These returnees were excluded from further analysis. Another 75 individuals $(32.1 \%)$ had the year of return identified, but either one or two of their resettlement locations (either the name of their birthplace, or the city they moved to upon returning to Spain, resettlement city) was missing. These individuals had their year of return included in the overall analysis but their resettlement movements were discounted. In regards to gender, of the 100 women included, 34 of them did not have sufficient data to track their resettlement movements, leaving only 66 returnees with all the necessary data. Likewise, of the 133 men, 41 had

\footnotetext{
${ }^{3}$ Exiliad@s Project, accessed March 2020, https://exiliadosrepublicanos.info/en/project
} 
insufficient data, which left 92 exiles. This study did not take into account whether individuals repatriated alone or with a spouse and children — all of which would perhaps dictate a different return strategy or a resettlement destination.

We defined a resettlement movement as the city (town, village, province or region) that the returnee settled upon returning to Spain. We thus created three separate types of movements. The first movement was for those who returned to the same city where they were born. If so, a number one was written in their data file. This classification also included individuals who moved to a different city-independent of size - if this new city was less than 50 kilometres away ${ }^{4}$. The distance being sufficiently large to account for spatial distance of extended family-kin networks. However, it does not account for the ease or difficulty of the various terrains in Spain (Mönkediek and Bras 2014, 247). The second movement was for those returnees who moved to a larger city in terms of its population (and the distance was greater than 50 kilometres from their birthplace). Individuals who fit this second movement pattern were identified with the number two. Lastly, the individuals who moved to a smaller city (farther than the aforementioned distance from their birthplace), were categorized with a number three, identifying our third movement. For comparison purposes, both the second and third movements are referred to herein as "elsewhere" when comparing them to the first resettlement pattern.

Finally, based on historical and academic accounts of social-political reprisals, we correlated general assumptions to each of the resettlement movements ${ }^{5}$. For the first movement (same or near place of birth), we assumed that there would be a strong link to the land, family or culture of the individual. As was the case, for example, with C. E. Lahoz Barrio, who after 20 years in exile in France, Bolivia, and Uruguay, returned to her native Sarrión, along with her husband and daughters in 1968. The following year, her elderly parents joined her from their country of exile, France. Her example highlights the strong bond to the land and family network she kept across time and distance.

\footnotetext{
${ }^{4}$ The rational being that if both cities were in the same region, and in small enough distance, a returning individual could readily access his or her former community or family's network. See Manuela Angelucci, et al. "Extended family networks in rural Mexico: A descriptive analysis." (2009).

${ }^{5}$ All of the aforementioned authors in the introduction paragraph mention the various punishments or retaliatory experiences suffered by those who returned to Spain.
} 
For the second movement (a bigger city farther away from the birthplace), we supposed that the individuals sought either anonymity, employment opportunities or was driven away by external or political pressures. As was the case with M. Vega de Iglesias, who combined her political objectives with her family obligations. Originating from the Santander province, she was first exiled in 1937 but returned once the war had finished to Madrid. She once again exiled herself for a second time in 1945 and finally returned in 1950 as a spy for the French government, moving once more to Madrid to both take care of her ailing father and continue her covert work ${ }^{6}$.

Our final and third assumption was for those individuals resettling to a smaller city. We assumed that they opted for a smaller community out of convenience, spousal connection (i.e. the spouse's birthplace region and family network), or that it led to a more advantageous existence. As was the case of S. Domenech Llin who in 1968 did not resettle in his native Alcoy, Alicante and instead opted for his wife's smaller city of Sarrión.

\section{RESULTS}

Table $n^{0}$ 1. Year, movement and percentage of return

\begin{tabular}{|l|c|c|c|c|}
\hline Years of return & $\begin{array}{c}\text { Total percentage } \\
\text { of returns. }\end{array}$ & $\begin{array}{c}\text { same city } \\
\text { (CASE 1) }\end{array}$ & $\begin{array}{c}\text { larger city } \\
\text { (CASE 2) }\end{array}$ & $\begin{array}{c}\text { smaller city } \\
\text { (CASE 3) }\end{array}$ \\
\hline $1939-1940$ & $6.4 \%$ & $78.6 \%$ & $14.3 \%$ & $7.1 \%$ \\
\hline $1941-1950$ & $13.3 \%$ & $52.5 \%$ & $38.1 \%$ & $9.5 \%$ \\
\hline $1951-1960$ & $11.1 \%$ & $77.8 \%$ & $22.2 \%$ & -- \\
\hline $1961-1970$ & $16.7 \%$ & $60.7 \%$ & $28.6 \%$ & $10.7 \%$ \\
\hline $1971-1980$ & $27.0 \%$ & $45.8 \%$ & $45.8 \%$ & $8.3 \%$ \\
\hline $1981-1990$ & $6.4 \%$ & $58.6 \%$ & $37.9 \%$ & $3.4 \%$ \\
\hline $1991-2000$ & $2.5 \%$ & $68.8 \%$ & $31.3 \%$ & -- \\
\hline $2001-2010$ & $2.5 \%$ & $72.7 \%$ & $27.3 \%$ & -- \\
\hline
\end{tabular}

Source: author

\footnotetext{
${ }^{6}$ UCSD, 'Spanish Civil War Memory Project', accessed July 3, 2008, https://library.ucsd.edu/speccoll/scwmemory/cat-alpha.html
} 
Once all categories were plotted by the year of return, a resettlement movement pattern emerged. The total breakdown was $58.2 \%$ moved to the same city, $34.8 \%$ to a larger city and $7.0 \%$ to a smaller city. Simplifying it, $58 \%$ returned to the same city or region and $42 \%$ chose elsewhere. This general breakdown, however, changed depending on the time period in which the return occurred. Chronologically, during the initial bellicose period from 1936-1939, 5.1\% of all our catalogued individuals fled and returned to Spain. The great majority of these $(92 \%)$, occurred after the war ended on April 1, 1939. These individuals were part of the more than 500,000 refugees who escaped the war and almost immediately returned or were repatriated back in the same year, or in 1940, by the French Government (Soo 2014, 44). Our database numbers correspond to the findings of other scholars who have examined how between AprilDecember of 1939, approximately 268,000 Republican exiles who were not especially involved in political causes were repatriated in great numbers (Vilar 2009, 72). The French Interior Minister at that time, Albert Sarraut, stated that refugees would be housed in camps with only what was necessary to prepare them for their expulsion or return to Spain (Del Árbol Cana 2010, 111). In Spain, Franco considered these people as "escapees" and as political criminals, subject to his Law of Political Responsibilities (Schwarztein 2001, 20-21). Thus, repatriation had grievous consequences for many men and women. Upon returning, they were separated from family members and imprisoned in labour camps, jails, or simply killed (Quintero Maqua 2016, 103).

Because of this vast forced repatriation, we combined the years 1939-1940 as a separate event from both the war and the subsequent decade. It totalled $6.4 \%$ of all returns in our database, where $79 \%$ of these individuals returned to their birth cities and $21 \%$ elsewhere. The rate of return for the year 1939-1940 was only superseded three decades later (1971-1980), where 27\% of all returns occurred. Noteworthy for this decade, $62 \%$ of these returns occurred in a three-year period (1975-1978), following the death of Franco in 1975. The subsequent three decades from 1981 to 2010 amounted to $11 \%$ of all returns.

The rates of returns can only be partially explained by certain historical events and social-political trends. As previously stated, the end of the Spanish Civil War triggered the 1939-1940 repatriation from France to Spain, which is observed in the data. Equally, the death of Franco in 1975 triggered a large rate of returns, not seen 
since the latter event. These two cases are positively correlated with their respective increase in returns. However, the rates of return for the decades between and after these two occurrences are not as easily interpreted. For example, one would expect an increase in returns after the end of World War II (September of 1945), followed by Franco's first general pardon in October of the same year, but there is none ${ }^{7}$. There is no statistical significance or increase in returns, even when factoring in a two-year timeframe of return (Escobar Deras 2019) ${ }^{8}$.

Following Franco's second pardon in 1954 however, there was a slight increase in returns when Republican exiles could then obtain a Spanish passport and visit Spain for up to 30 days $^{9}$. The cause of this may well be a compounding effect of the previous pardon, coupled with Spain joining the United Nations (UN) in 1955. Nevertheless, there is no direct correlation between these events and a higher rate of return. Similarly, in the year 1984-1985, there was an increase in returns and some of the possible factors may have started two year prior in 1982 when Spain joined the North Atlantic Treaty Organization (NATO), or the Spanish General Elections where the Spanish Socialist Workers Party (PSOE), gained power. Perhaps still, it was influenced by the return of Maria Zambrano (returned in 1984), after which newspapers declared the "exile" period to be over, which may have encouraged other individuals to return (Alted Vigil 2014, 27).

The earlier in Franco's rule the greater the danger for those individuals returning. Franco's Law of Political Responsibility (1939) lasted three decades and it held that any assistance to The Republic was a crime (Schwarztein 2001, 20). Individuals were still being "acquitted" of wrongdoing in 1969 (Rickett 2015, 149). Even with this law, based on our dataset, more than half (64\%) of all exiles returned in this time period. Of course, it is not the same to speak of the first Francoism period (Primer franquismo 1939-1959), than of the later Francoism (Segundo franquismo

\footnotetext{
${ }^{7}$ Decreto de 9 de octubre de 1945 por el que se concede indulto total a los condenados por delito de rebelión militar y otros cometidos hasta el 1. ${ }^{\circ}$ de abril de 1939. Agencia estatal Boletín Oficial del Estado (BOE), https://boe.es/datos/pdfs/BOE/1945/293/A02430-02431.pdf

${ }^{8}$ The timeframe of return generally ranged from six months to two years.

${ }^{9}$ Decreto de 25 de julio de 1954 de Indulto General con motivo del Año Mariano y del Año Jacobeo.

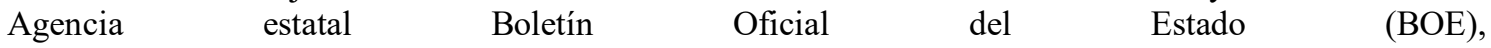
https://www.boe.es/datos/pdfs/BOE//1954/206/A05094-05094.pdf. See also Rosy Rickett, 'Refugees of the Spanish Civil War' (doctoral thesis, University of Manchester, 2014), 132.
} 
1959-1975), where, in the latter case, Francoist repression was more lenient as the country began to economically open towards the outside; shifting away from autarchy and starting a period of economic growth (Rickett 2015, 91). However, punitive and vindictive social-political controls still remained as exemplified by the three-member Osaba family upon their return from France in $1959^{10}$. M. O. Fernandez Osaba and his wife F. B. Osaba, after 20 years in exile, moved back to the same city with their Frenchborn 14-year-old daughter. After ten years in Spain, they were compelled to move to Madrid due to the continuous harassment and vandalism of their lands by the locals for being rojos.

In total, during Franco's 35-year dictatorship (1939-1975), 64\% of first generation exiles returned to Spain, and $65 \%$ of these moved to their city of origin while $35 \%$ chose elsewhere $(26.0 \%$ to a larger city, $9.0 \%$ to a smaller city and $16 \%$ were unknown). Moreover, by 1969 almost half (46\%) of all exiles in our dataset had returned. They had met all the bureaucratic requirements and penalties the regime imposed on them to do so. In regards to their resettlement movements by this year, $65 \%$ chose their city of origin and 35\% elsewhere (26.9\% opted for a larger city and $7.7 \%$ a smaller city). These rapidly increased in the following five years (1970 to 1975), where an additional $19 \%$ returned to mixed receptions in both their families and communities (González Martínez 2010, 85). In these last five years, their resettlement movements were almost identical to the previous decades: $64 \%$ returned to their city of birth and $36 \%$ chose elsewhere ( $31.8 \%$ moved to a larger city and 4.5 to a smaller city).

After Franco's death, the pattern inverted. The total percentage of returning exiles was $36 \%$ (1976-2010). Specifically, $47 \%$ of the returnees relocated to their city of origin and $53 \%$ chose elsewhere $(47.0 \%$ to a larger city, $6.0 \%$ to a smaller city and $16.0 \%$ were unknown). Of note, $29 \%$ of all these returnees arrived within the span of two years (1976-1978); of which 68\% moved to larger cities to affect political change (Escobar Deras 2019, 27).

\footnotetext{
${ }^{10}$ Interview of Elsa Osbaba, conducted by Mauricio Escobar Deras and Lidia Bocanegra-Barbecho, Granada, 18 June 2018.
} 


\section{Image $n^{0}$ 1. Resettlement movement patterns 1936-2010}

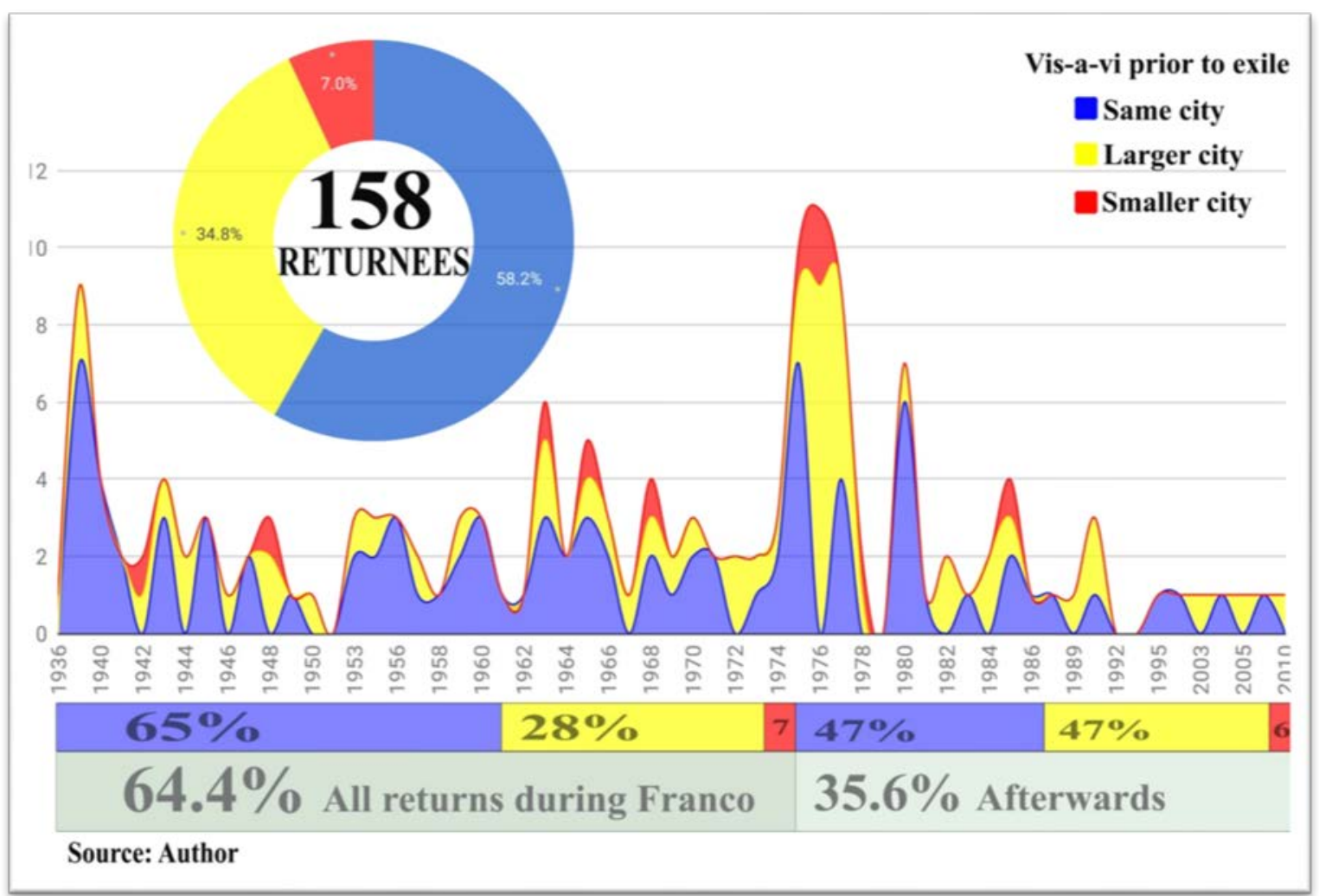

Source: Author

\section{GENDER}

Gender differences were also apparent in the rates of returns and in the individual movements. Of the 158 first-generation returnees, 66 were women and 92 men. During Franco's dictatorship, 70\% of the women returned and 30\% did so after his death. For the men, 59\% returned during Franco and 41\% afterwards. Focusing on each resettlement movement, women displayed a much higher preference to return to their city of origin than the men. They relocated to their birthplace at $68 \%$ and $32 \%$ elsewhere $(27.3 \%$ to a larger city and $4.5 \%$ to a smaller one); whereas men, were more equally divided, $51 \%$ relocated to the same city and $49 \%$ elsewhere $(40.2 \%$ to a larger city and $8.7 \%$ to a smaller city). We reasoned that men did not return to their hometowns, or even Spain, at the same rates as the women during both Francoist 
periods due to the stringent social-political pressures, mostly in the form of the aforementioned political and social reprisals. We believe these align with the regime's socio-economic punishments that were ordinarily directed towards men, and to a lesser degree, women (Wyoming Fees 2007, 8).

The data demonstrates an overall preference for returning exiles to resettle to their native cities. Because of this, we focused on those individuals that opted for "elsewhere" to better highlight atypical returns. The first woman in the dataset to choose elsewhere to relocate was C. C. Godessart from Alcalá de Gurrea. Seeking anonymity, she resettled in the larger city of Tarragona in 1944 after returning from France where she was imprisoned at the border. Six years later, M. Vega de Iglesias from Cantabria, opted for the same as she resettled in Madrid to take care of her then prison-released father who was "physically broken" ". Similarly, the first women opting to resettle in a "smaller" city occurred almost three decades after the end of the Civil War, in 1965, when R. García Ascot from Madrid, exiled in Mexico, settled in Lugo after 26 years abroad (Carredano 2015, 81). The second woman to do so was A. R. Ruíz from Santander, who after 36 years in France working menial jobs, retired to Lloret del Mar in 1975. These individuals underline the tremendous preference for the city of birth, for so few chose otherwise.

Men choosing "elsewhere" to resettle, and thus circumventing their city of birth, occurred earlier in our timeline and with more frequency. The first instance of a man moving to a larger city occurred at the end of the war in 1939, when 67-year-old Q. Lavilla Navascues (exiled in 1936), moved to Guipuzcoa from Tudela. The second to do this was A. Paz, originally from Almería (exiled in 1939), who moved to Barcelona in 1942. He was later imprisoned until 1952, where once liberated, he exiled himself a second time till 1979 (Venza 2019). Likewise, choosing a smaller city first occurred during the first year of the Civil War in 1936, when J. L. Muñoz from Vitoria, was exiled and returned the same year but resettled in Girona, away from the then frontlines. The first relocation to a smaller city after the Civil War occurred in 1941 when J. P. Belis from Barcelona (exiled in 1939), was forcefully repatriated back and subsequently executed in Valencia (Abdón 2015, 120). These movements do not follow freely-chosen

\footnotetext{
11 Marina Vega de la Iglesia, UCSD "Spanish Civil War Memory Project." July 3, 2008. https://ibrary.ucsd.edu/speccoll/scwmemory/cat-alpha.html.
} 
resettlement options and serve to highlight the severe reprisals awaiting many returnees. Finally, the first freely chosen movement to a smaller city occurred in 1948 when A. Z. Blanco, a Soviet niño de Guerra from Gijón, who was captured by German forces and ultimately repatriated by Franco's regime, chose to move to San Martín del Rey Aurelio (Vigil 1999, 81, 84).

Of significance, directly following Franco's death, the rate of returns (as compared to other decades and time periods), briefly spiked for both women and men. Women's resettlement movements favoured the aforementioned trend with a slight increase in the second and third elsewhere relocations. Men's patterns on the other hand were radically different from their previous resettlement progression. The percentage of men choosing to relocate to a larger city jumped to $50 \%$, all occurring in a three year span from 1975 to 1977 . Overall, these individuals would not have returned while Franco lived due to ideological purposes, and to have done so would also have been dangerous to their persons. Therefore, we surmised that these returnees opted for larger cities for two reasons: first, the familial link to their ancestral homes and communities no longer existed; and second, they were politically driven and wanted to effect broad changes in Spanish politics (Escobar Deras 2019, 30).

We also found that the resettlement movement followed a gender and an age progression pattern. For women, the average age upon their return was 50 years old. However, while Franco was in power, the average age of return was 42, and 68 after his death. When focusing separately on the individual time periods, a more marked pattern emerged. In the first resettlement movement, women who returned to their city of origin were on average 44 years old. However, during Franco's reign, the age was 39 and 67 after his death. In the second movement, women's overall age averaged 58 years old, 46 during Franco and 72 after him. Finally, women who moved to a smaller city were on average 68 years old, 60 during Franco and 83 after his death. This age progression indicates a rudimentary principle where the younger the woman was upon her return, the greater the chance she would return to her city of origin. Likewise, though proportionally less, the older the woman, and by general extension the longer the exile period, the greater loss there was to the familial link. This in turn would result in the individual resettling elsewhere. This indicates that for older women, the connection to 
the physical place of origin was more of an abstract memory rather than the actual corporal space (de Hoyos Puente 2012, 98).

Men in general were older than women when they returned to Spain. However, their resettlement movements did not follow the same age progression. The overall average for men was 56 years old upon their return, 49 during Franco's rule and 69 afterwards. For the first resettlement movement, they were 56 years old when doing so, 51 during Franco and 68 after him. In the second movement, they averaged 60 years old, 51 during Franco's rule and 68 afterwards. For the third and final movement, the relative age progression changed from that of the trend. The average age was 49 years old, 36 during Franco and 71 after him. Evidently, and unlike women, 48.9\% of men sought a different resettlement city from their birthplace at a younger age and throughout both time periods of Franco's rule-indicating a desire for change at the very least, and a greater need for anonymity and from reprisals.

Image $n^{0}$ 2. Gender resettlement movement patterns 1936-2010 


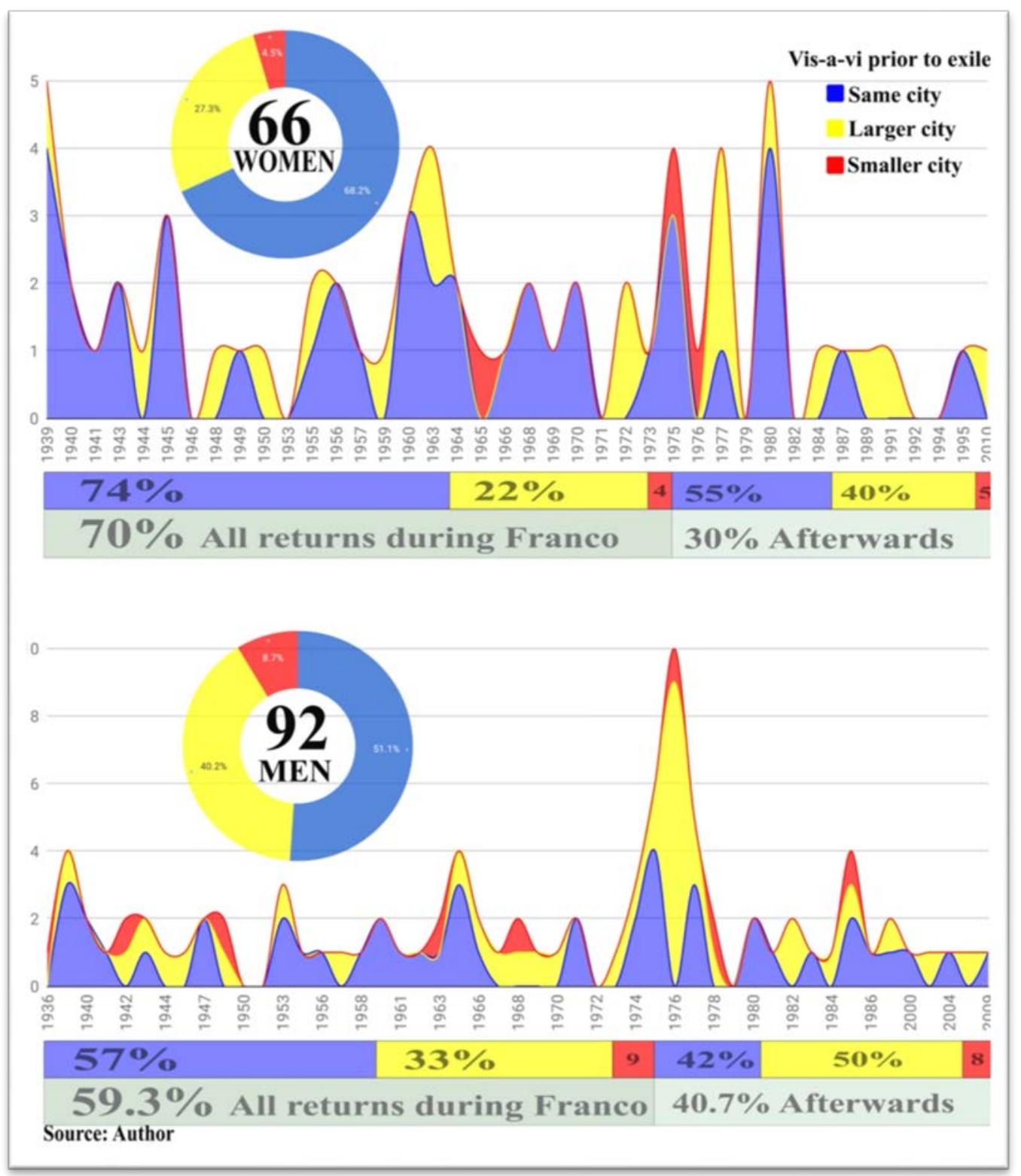

Source: Author

\section{CONCLUSION}

Our aim was to begin a dialogue of the various repatriation movements of first generation exiles as they resettled back into Spanish society, and determine, if the broader general trends could be identified from a relatively small number of individuals. The dataset of 233 people, that have subsequently been narrowed down to 158 individuals, does not represent the thousands of individuals who returned to Spain - and 
it would be disingenuous to say that these data patterns serve as accurate indicators of the entire return experience. However, we can infer seven general patterns that can be carefully adapted to the whole. First, the return to Spain was not uniform due to the various international political factors influencing individuals and their return strategies. Second, the return frequency gradually increased during the 1950s. Third, the majority of returns happened while Franco was in power, and therefore, were more costly, difficult and troublesome for the individual. Fourth, immediately after Franco's death, there was an exponential increase in returns that lasted for five years, with the majority occurring in the first two years following his death. Fifth, the majority of women chose to return to their city of origin. At (68\%), they had a greater inclination to live in their respective hometowns, and to a lesser extent, the men did as well at 51\%. For the former, there was an age pattern whereby the younger the woman was upon her repatriation to Spain, the more likely she was to return to her city of origin. The various factors associated with this decision ranged from the existence of familial ties, age and ease of re-adaptation (affiliation), to the local social culture.

Sixth, women did not have the same felonious political responsibilities as men and were thus more able to return to their hometowns unimpeded. Franco's regime saw women as weaker and less of a threat than men. This meant that women faced less risk of persecution, prosecution or retaliation, allowing them comparatively more freedom to return unrestrained (Vigil 1999, 199). Such was the case through the 1956-1959 repatriation of Spanish-Soviet children of war, where the government feared the foreignborn husbands but not the wives. The Spanish government barred any Spanish born woman married to a Russian man from returning to Spain. This perceived threat could explain the limitations placed on men and why only $51 \%$ of our datasets opted for the first movement to their original cities.

Finally, men chose different resettlement options at different frequencies and rates than women. Unlike women, there were no age-related movement patterns among the men. As for the reasons why $49 \%$ chose elsewhere to resettle, it can be broadly correlated to various factors ranging from persecution, job availability and even political aspirations after Franco's rule. However, further studies with a larger database would help affirm our conclusions and gain a better understanding of the phenomenon as a whole. 


\section{BIBLIOGRAPHY}

Alted Vigil, Alicia. "Repatriation or Return? The Difficult Homecoming of the Spanish Civil War Exiles," in Coming home v. 1., edited by Gemie, Sharif and Scott Soo. pp. 16-34. Cambridge Scholar Publishing, New Castle: Cambridge Scholar Publishing, 2014.

Alted Vigil, Alicia, María Encarna Nicolás Marín, and Róger González. Los niños de la guerra de España en la Unión Soviética: de la evacuación al retorno, 19371999. Madrid: Fundación F. Largo Caballero, 1999.

Angelucci, Manuela, Giacomo de Giorgi, Marcos A. Rangel, and Imran Rasul. "Extended family networks in rural Mexico: A descriptive analysis." Tucson: IZA, 2009.

Bocanegra Barbecho, Lidia. "La web 2.0 y el estudio del exilio republicano español: E1 análisis de la movilidad social y el retorno a través del proyecto e-xiliad@s" in Otras voces, otros ámbitos: Los sujetos y su entorno. Nuevas perspectivas de la historia sociocultural, Valencia: Asociación de Historia Contemporánea, (2015): 59-65.

Bocanegra Barbecho, Lidia. "Memoria, exilio republicano e historia digital: El proyecto e-xiliad@ s", Quiroga: Revista de Patrimonio Iberoamericano n6 (2014): 60-63.

Bocanegra Barbecho, Lidia. Exiliad@s Project, in Visualizing Objects, Places, and Spaces: A Digital Project Handbook, PubPub: Duke University, 2021, D.O.I. https://doi.org/10.21428/51bee781.8836e6d4.

Bustillo Cuestas, Josefina. Retornos de exilios y migraciones. Madrid: Fundación F. Largo Caballero, 1999.

Carredano, Consuelo. "Un sendero sobre esta tierra roja. Miedo, censura, retornos. La experiencia vital de los músicos españoles antes y durante su exilio en México: tres estudios de caso." Quintana. Revista de Estudios do Departamento de Historia da Arte n¹4 (2015): 81-104.

Escobar Deras, Mauricio. "A methodological approach to first Generation Spanish Republican exile return", Quiroga: Revista de Patrimonio Iberoamericano n¹5 (2019): 20-30.

Gonzalez Martínez, Carmen. "El retorno a España de los niños de la guerra civil," Anales de Historia contemporánea, n¹9 (2010): 75-100.

Hoyos Puente, Jorge de. "Pensando en el regreso. Las organizaciones políticas del exilio republicano en México frente al ocaso del franquismo y la transición española." Historia Social, n 74 (2012): 85-101.

Mateos, Abdón. Exilios y retornos. Madrid: Eneida, 2015.

Mönkediek, Bastian and Hilde Bras. "Strong and weak family ties revisited: reconsidering European family structures from a network perspective." The History of the Family 19, $\mathrm{n}^{\circ} 2$ (2014): 235-359. https://doi.org/10.1080/1081602X.2014.897246 
Ortuño Martínez, Bárbara. "Jóvenes expatriadas. Un acercamiento al compromiso político de la segunda generación del exilio republicano en Argentina durante los años sesenta y setenta," Ayer n ${ }^{\circ} 100$ (2015): 123-147.

Pozo-Gutiérrez, Alicia and Scott, Soo. "Categories of return among Spanish refugees and other migrants 1950s-1990s: Hypotheses and early observations," Les Cahiers de Framespa. Nouveaux champs de l'histoire sociale, 5, $\mathrm{n}^{\circ} 5$ (2010). https://doi.org/10.4000/framespa.92

Quintero Maqua, Alicia Berta. "El eco de los presos: los libertarios en las cárceles franquistas y la solidaridad desde fuera de la prisión, 1936-1963”. Doctoral thesis, Universidad Complutense de Madrid, 2016.

Rickett, Rosy. "Refugees of the Spanish Civil War and those they left behind: personal testimonies of departure, separation and return since 1936". Doctoral thesis, University of Manchester, 2015.

Ruiz del Árbol Cana, Antares. "Voces entre alambradas: los primeros pasos del exilio español en Francia. Una historia que aún se está escribiendo" Millars: espai $i$ historia, $\mathrm{n}^{\circ} 33$. (2010): 107-126.

Sánchez Vázquez, Adolfo. Del exílio en México: recuerdos y reflexiones. Editorial Grijalbo, 1997.

Schwarztein, Dora. Entre Franco y Perón: Memoria e identidad del exilio republicano español en Argentina. Madrid: Ed. Crítica, 2001.

Soo, Scott. ed., Coming Home? Vol. 1: Conflict and Return Migration in the Aftermath of Europe's Twentieth-Century Civil Wars (Vol. 1). Cambridge Scholars Publishing: Newcastle, 2014.

Vega de Iglesias, Marina. UCSD, 'Spanish Civil War Memory Project', July 3, 2008. https://library.ucsd.edu/speccoll/scwmemory/cat-alpha.html.

Venza, Cládio. Remembering Diego Camacho AKA Abel Paz. Last modified April 16, 2009. https://www.katesharpleylibrary.net/4qrg70

Vilar, Juan B. El exilio español de 1939 en el Norte de Africa' in ;Ay de los Vencidos! El exilio y los países de acogida. Madrid: Editorial Eneida (2009): 71-102.

Wyoming Fees, Evelyn. "Making women matter: Spain's long road toward gender equality". Master's Thesis, University of North Carolina at Chapel Hill. 2007. 